\title{
Methyl-CpG-Binding Domain Protein 1
}

National Cancer Institute

\section{Source}

National Cancer Institute. Methyl-CpG-Binding Domain Protein 1. NCI Thesaurus. Code C148504.

Methyl-CpG-binding domain protein 1 ( $605 \mathrm{aa}, \sim 67 \mathrm{kDa}$ ) is encoded by the human MBD1 gene. This protein plays a role in the repression of gene expression. 